\title{
Composition and structure of forest communities in a fragmented rural landscape: the Middle Hills of Eastern Nepal
}

\begin{abstract}
K. N. L. Magraw ${ }^{1}$ and J. K. Detling²
Rising population and land use intensification in the Middle Hills (1,000-3,000 m elevation) of Nepal have resulted in widespread conversion of primary forests, and there is limited understanding of the degree to which conversion affects plant community composition. This study describes and compares vascular plant communities in four vegetation types in the eastern Middle Hills of Nepal: primary forests, deforested areas, large cardamom (Amomum subulatum) plantations, and conifer plantations. We sampled nested plots in 18 stands and we analyzed indicators such as species richness and diversity, unique species, stand composition, and structure. Primary forests and conifer plantations had significantly greater species richness than deforested areas and cardamom plantations $(\mathrm{P} \leq 0.001)$. Primary forests exhibited complex structure and contained $\sim 229$ species, $30 \%$ of which were unique to this vegetation type. Deforested areas contained sparse woody vegetation, many species suited to exposed habitats, and $\sim 178$ species. Cardamom plantations contained $\sim 174$ species and were characterized by an Alnus nepalensis overstory ( $82.4 \%$ of stems $\geq 3.2$ $\mathrm{cm} \mathrm{dbh)} \mathrm{and} A$. subulatum in the understory. Conifer plantations were stocked with Cryptomeria japonica, Pinus wallichiana, or Pinus roxburghii. Of $\sim 217$ species encountered, only $16 \%$ were unique to this vegetation type, although species diversity was comparatively high (Shannon-Wiener index: 3.34). Our findings indicate that vegetative composition was influenced by (a) the degree of disturbance and management and (b) aspect and elevation, and therefore plant community composition in primary forests is unlikely to be approximated in other vegetation types or in forests positioned differently on the landscape.
\end{abstract}

Key words: Disturbance, forest conservation, llam District, resource management, species richness

$\mathrm{T}_{\mathrm{a}}^{\mathrm{s}}$ he eastern Middle Hills of Nepal support a disproportionately large number of plant species in a country known for its floral diversity (TISC/NARMSAP, 2002), 5,636 species of gymnosperms and angiosperms and 534 pteridophytes have been recorded in Nepal (DPR, 2001, 2002). Although plant species in eastern Nepal's Middle Hills have been documented since 1848 (Hara, 1966; Stainton, 1972; Rai, 1999) sampling has been patchy and incomplete, and there has been no quantitative assessment of plant community composition.

Since the late $18^{\text {th }}$ century, Nepal's population has been steadily rising and markets for agricultural and forest products have greatly expanded. As land-use has intensified, primary forests have been converted to cropland and managed forests, or have experienced unsustainable resource extraction (Blaikie, 1988; Brown and Shrestha, 2000; Chaudhary, 2000). Beginning in the 1950s,
Nepal's government introduced numerous policies to address the decline in forest cover and increase revenues from the land (Metz, 1991; Chaudhary, 2000; HMGN/MFSC, 2000). Because large contiguous protected areas are not feasible in the densely populated Middle Hills, the government has supported plantation establishment in Community and Leasehold Forests on deforested state-owned lands. Likewise, private landowners have adapted by establishing plantations and planting trees alongside their crops (Gilmour, 1995; Paudel and Thapa, 2001; Acharya, 2006).

State-sponsored replanting programmes and private landowners' efforts have offset the decline in forest cover in this region (Branney and Dev, 1994; Shrestha, 1998; Gautam et al., 2003). However, scant attention has been paid to the accompanying changes in composition of forests and the potential loss of biological diversity (UNDP, 1998; Mikkola, 2002). Introduced

${ }^{1}$ Ecology and Department of Biology, Colorado State University, Fort Collins Colorado 80523-1878 USA. E-mail: kim magraw@ios.doi.gov ${ }^{2}$ Department of Biology and Natural Resource Ecology Laboratory, Colorado State University, Fort Collins, Colorado 80523-1878 USA 
conifers are often preferred for governmentsponsored plantation programs (Schreier et al., 1994; Branney and Yadav, 1998; Jackson et al., 1998). Sitaula (2000) and others have reported that pine plantations exhibit lower plant species richness and diversity than primary or mixed broad-leafed forests in the Central and MidWest Regions of Nepal. Similarly, Ibscher (1999) found lower plant diversity in 'disturbed' forests than in 'undisturbed' forests. In Central Nepal's Middle Hills, Acharya (1999) recorded greater tree species richness in 'intermediate disturbance' plots as compared to 'low disturbance' and 'high disturbance' plots. Plant community composition in private plantations has not been assessed.

The objective of this research was to describe and compare the vegetative composition and structure of plant communities in four vegetation types in the northern Lower Temperate Zone of Ilam District. The vegetation types were: (a) primary forests, representing the natural vegetation; (b) deforested areas, which have experienced a high degree of resource extraction, primarily tree felling, fuel-wood cutting, and regular grazing; (c) large cardamom (Amomum subulatum) plantations, private intensively managed cash-crop systems; and (d) conifer plantations, part of the government-supported afforestation effort. We hypothesized that primary forests would exhibit the greatest species richness and diversity, followed by conifer plantations, and that cardamom plantations and deforested areas would contain the lowest species richness and diversity.

\section{Materials and methods}

\section{Study site}

The study site lies between $27^{\circ} 00^{\prime}$ and $27^{\circ} 05^{\prime} \mathrm{N}$ latitude and $87^{\circ} 55^{\prime}$ and $88^{\circ} 00^{\prime} \mathrm{E}$ longitude in the northern part of Ilam District, Nepal (Fig. 1). We sampled stands within a $\sim 30 \mathrm{~km}^{2}$ area in four Village Development Committee (VDC) areas: Sulubung, Mabu, Maimajhuwa, and Maipokhari. Sampling was carried out within 1,950-2,550 m elevation, corresponding closely with the limits of the LowerTemperateZone(TISC/ NARMSAP, 2002). Northern Ilam experiences a monsoon climate, with the majority of the $\sim 2,500 \mathrm{~mm}$ annual precipitation occurring from June to October. Mean daily temperature ranges from $10^{\circ} \mathrm{C}$ in winter to $15^{\circ} \mathrm{C}$ in summer. Direct sunlight is limited due to the steep topography and frequent cloud-cover.

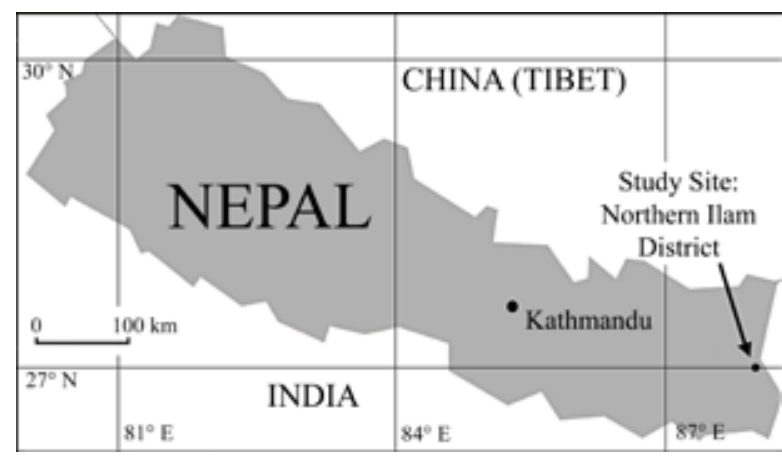

Fig. 1: Map of Nepal showing location of study site in the eastern Middle Hills

Primary forests are found in isolated patches surrounded by a complex mosaic of agriculture, deforested land, plantations, and human settlements. They contain elements of three vegetation types described by Stainton (1972): (a) Castanopsis tribuloides - Castanopsis hystrix forests, $\sim 1,850-2,150 \mathrm{~m}$ elevation; (b) Quercus lamellosa forests, $2,000-2,600 \mathrm{~m}$; and (c) Lithocarpus pachyphylla forests, $\sim 2,450-2,900 \mathrm{~m}$, found only in far Eastern Nepal. These vegetation types are characterized by species in Fagaceae and Lauraceae, and are noted for their diverse understory, including ferns, epiphytes, climbing plants, and orchids (Stainton, 1972; TISC/NARMSAP, 2002). For the purposes of this study, primary forests are those with a naturally generated overstory dominated by tree species commonly associated with the above vegetation types. Sporadic human activity, such as livestock grazing or fuel-wood removal, was evident in all sampled primary forests.

In deforested areas, wood cutting, frequent livestock grazing, and other resource extraction have removed the overstory and prevented regeneration. It is likely that some deforested areas were previously used to grow crops, but then left fallow. There are shrubs and occasionally trees, but the majority of the vegetation is herbaceous.

Cardamom plantations are common in riparian corridors on private land up to $\sim 2,050 \mathrm{~m}$. This cash-crop (a spice) is lucrative and the land can be used simultaneously to grow fodder, timber, and fuel-wood (Sharma et al., 1998b). Cardamom is usually planted underneath an Alnus nepalensis (Nepalese Alder) canopy with a number of fodder tree species, such as Ficus auriculata, Leucoseptrum canum, and Saurauia napaulensis, in the understory (Sharma et al., 1998a; Narmsaling Community Development Center, 2002) 
Conifer plantations are community forests that were once deforested but have since been planted with one or more of Cryptomeria japonica, Pinus wallichiana, and Pinus roxburghii. The conifer stands sampled in this study were immature (10-30years) because community forest plantation efforts had only recently become widespread.

At the study site, south- and east-facing slopes have the greatest density of human settlements, and hence the majority of the cardamom plantations and deforested areas we sampled were south- and east-facing. North- and west-facing mountainsides have become the state-owned community-managed forests containing the primary forests and conifer plantations available for study. Because population is denser and agriculture more intensive at lower elevation, and because cardamom cannot be grown profitably above $\sim 2,050 \mathrm{~m}$, primary forests are generally limited to higher elevation areas. Among the stands sampled, the lowest elevation vegetation type was cardamom, averaging $1,960 \mathrm{~m}$, and the highest was primary forest, averaging $2,250 \mathrm{~m}$.

\section{Methodology}

Data were collected from August 1 - October 6, 2002. We sampled 18 stands selected randomly from a list of potential sites: four primary forests, four conifer plantations, five deforested areas, and five cardamom plantations. Political instability at the time of the study precluded visiting a fifth primary forest stand and a fifth conifer plantation.

Sampling followed the United States Forest Service's Forest Inventory and Analysis Phase 3 Vegetation Indicator methodology (USDA Forest Service, 2005) which utilizes nested plots to provide a multi-scale assessment of species richness and abundance (Fig. 2). In each stand, data were collected in three $170 \mathrm{~m}^{2}$ circular plots. An effort was made to space the plots regularly within each stand. Where there was significant relief $(>100 \mathrm{~m})$, the plots were stratified by elevation. From the center of each plot, three stakes were placed at $7.32 \mathrm{~m}$ horizontal distance along the $30^{\circ}, 150^{\circ}$, and $270^{\circ}$ azimuths to establish the plot boundaries. Next, three $1 \mathrm{~m}^{2}$ square quadrats were demarcated $4.57 \mathrm{~m}$ from the center stake along these azimuths. Within the $1 \mathrm{~m}^{2}$ quadrats we estimated total vascular plant cover and cover for each vascular plant species to the nearest $1 \%$ for all living plants $<1 \mathrm{~m}$ tall. Plants occupying $<1 \%$ of a quadrat were recorded as $0.5 \%$ cover. Percent subcanopy closure by cardamom was recorded between one and two meters above ground to the nearest $5 \%$ in quadrats of three cardamom plantation stands.

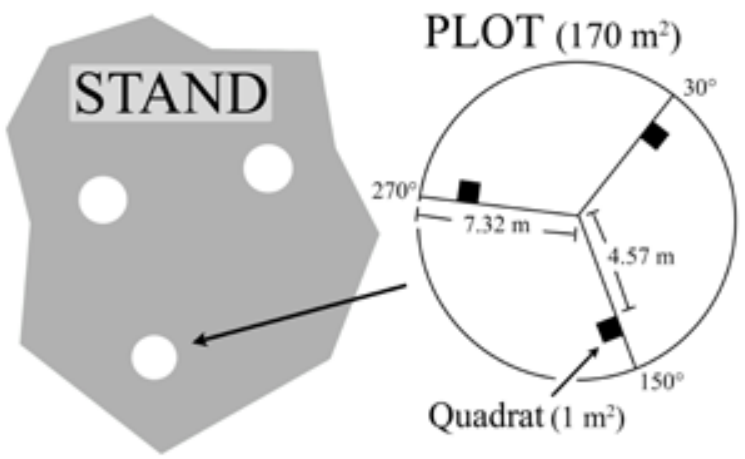

Fig. 2: Sampling design for the United States Forest Service's Inventory and Analysis Phase 3 Vegetation Indicator methodology

From the $170 \mathrm{~m}^{2}$ plots, a record was made of all vascular plant species not already encountered in the quadrats. Elevation, aspect, slope, crowncover to the nearest $5 \%$, and evidence of fodder cutting, trampling, and grazing were also recorded. Diameter at breast height (dbh) was measured for all woody stems $\geq 3.2 \mathrm{~cm} \mathrm{dbh}$. Stems $\geq 3.2 \mathrm{~cm}$ and $<10 \mathrm{~cm}$ dbh were categorized as 'small woody stems,' while those $\geq 10 \mathrm{~cm}$ dbh were categorized as 'trees.' Quadratic mean diameter at breast height was calculated for trees.

Shannon-Wiener diversity indices $\left(\mathrm{H}^{\prime}\right)($ Gurevitch et al., 2002) were calculated for each stand using plant species cover estimates in $1 \mathrm{~m}^{2}$ quadrats:

$\mathrm{H}^{\prime}=-\sum_{\mathrm{L}=1}^{\mathrm{S}} p_{i} \ln p_{i}$

where $s$ is the number of species in the sample and $p_{i}$ is the mean percent cover of each species in all nine quadrats in a stand. $\mathrm{H} \phi$ values reported herein are the mean of all stands in a vegetation type.

Species overlap among vegetation types was compared using Jaccard's Coefficients (S) (Jaccard, 1901):

$\mathrm{S}=a /(a+b+c)$

where $a$ is the number of species two vegetation types have in common and $b$ and $c$ are the number of species that are unique to each. 
Among the four vegetation types the following comparisons of means were calculated with SYSTAT (Wilkinson, 2000) using two-way analysis of variance (ANOVA) and Tukey's post hoc test for significance: species richness in $170 \mathrm{~m}^{2}$ plots and $1 \mathrm{~m}^{2}$ quadrats, vegetation cover in quadrats, $\mathrm{H} \phi$ in stands, mean dbh of trees in stands, densities of trees and small woody stems in stands, basal area $\left(\mathrm{m}^{2} / \mathrm{ha}\right)$ in stands, and species richness of climbing plants, epiphytes, and herbaceous graminoids in plots.

Nomenclature used in this study corresponds with that of Nepal's Department of Plant Resources' enumerations of vascular plants (DPR, 2001, 2002).

\section{Results and discussion}

\section{Findings}

Of the $\sim 391$ vascular plant species recorded (Table 1), 248 were identified to species, 294 to genus, and 324 to family. Our analyses include all species recorded, and thus numbers of species cited are often approximate (denoted by " "). In total, 217 genera, 90 families, 256 dicots, $\sim 78$ monocots, $\sim 53$ pteridophytes, and 4 conifers were enumerated.

\section{Primary forests}

C. hystrix and Symplocos ramosissima accounted for more than $82 \%$ of the stems of overstory tree species in primary forests (Table 2). The two stands in which $C$. hystrix was present were at $\sim 2,100$ m elevation, whereas the remaining two stands were at $\sim 2,400 \mathrm{~m}$ and $\sim 2,500 \mathrm{~m}$ elevation and contained tree species such as Alangium alpinum, L. pachyphylla, Quercus glauca, and Q. lamellosa. Other overstory species encountered sporadically were Ilex sikkimensis, Lyonia ovalifolia, Magnolia campbellii, Rhus wallichii, and Tsuga dumosa. There were $\sim 40$ woody understory species in primary forests, more than in any other vegetation type (Magraw, 2004).

In total, $\sim 229$ species were encountered in primary forests (Table 1). Richness of climbing and epiphytic plant species was significantly greater in primary forests than in the other vegetation types (Table 1).

\section{Deforested areas}

Deforested areas had a nearly continuous carpet of herbaceous foliage usually less than $20 \mathrm{~cm}$ high. Notable in this vegetation type are herbaceous graminoids and plants with a spreading growth

Table 1: Vegetative statistics for four vegetation types in northern Ilam District, Nepal

\begin{tabular}{|c|c|c|c|c|c|}
\hline & $\begin{array}{l}\text { Primary } \\
\text { Forests }\end{array}$ & $\begin{array}{l}\text { Deforested } \\
\text { Areas }\end{array}$ & $\begin{array}{l}\text { Cardamom } \\
\text { Plantations }\end{array}$ & $\begin{array}{c}\text { Conifer } \\
\text { Plantations }\end{array}$ & All \\
\hline Stands (plots) sampled & $4(12)$ & $5(15)$ & $5(15)$ & $4(12)$ & $\begin{array}{c}18 \\
(54)\end{array}$ \\
\hline Total species recorded ${ }^{1}$ & $\sim 229$ & $\sim 178$ & $\sim 174$ & $\sim 217$ & $\sim 391$ \\
\hline Unique species ${ }^{1,2}$ & $\sim 69$ & $\sim 47$ & $\sim 34$ & $\sim 37$ & -- \\
\hline \multirow{2}{*}{$\begin{array}{l}\text { Unique species }(\% \text { of total } \\
\text { species) } \\
\text { Mean vegetation cover }(<1 \mathrm{~m} \\
\text { high) }\end{array}$} & $30 \%$ & $26 \%$ & $21 \%$ & $16 \%$ & -- \\
\hline & $82.7 \%(A)$ & $87.0 \%(A)$ & $68.0 \%(B)$ & $69.7 \%(B)$ & -- \\
\hline Shannon-Wiener index $(\mathrm{H} \phi)$ & $3.10(A, B)$ & $2.98(A, B)$ & $2.57(A)$ & $3.34(B)$ & -- \\
\hline \multicolumn{6}{|c|}{ Mean species richness $\left(\mathrm{No} . / 170 \mathrm{~m}^{2}\right)$ of selected functional groups } \\
\hline Climbing plants & $14.5(A)$ & $2.3(D)$ & $5.9(C)$ & $9.8(B)$ & -- \\
\hline Epiphytic plants & $10.2(A)$ & $1.3(C)$ & $3.9(B)$ & $2.9(B, C)$ & -- \\
\hline Herbaceous graminoids & $2.3(C)$ & $9.5(A)$ & $2.5(C)$ & $3.7(B)$ & -- \\
\hline
\end{tabular}

Within a row, $A, B, C$, and $D$ are significantly different at $\mathrm{P}<0.05$.

${ }^{1}$ Some species were not positively identified, thus numbers of species are approximate.

${ }^{2}$ Seven unique species to cardamom plantations and three unique species to conifer plantations were cultivated trees. 
Table 2: Most abundant overstory tree species in three vegetation types in northern Ilam District, Nepal

\begin{tabular}{|c|c|c|c|c|c|}
\hline \multicolumn{2}{|c|}{ Primary forests } & \multicolumn{2}{|c|}{ Cardamom plantations } & \multicolumn{2}{|c|}{ Conifer plantations } \\
\hline Species & $\begin{array}{l}\text { OV } \\
\text { stems } \\
(\%)\end{array}$ & Species & $\begin{array}{l}\text { OV } \\
\text { stems } \\
(\%)\end{array}$ & Species & $\begin{array}{l}\text { OV } \\
\text { stems } \\
(\%)\end{array}$ \\
\hline $\begin{array}{l}\text { Castanopsis hystrix } \\
\text { Miq. }\end{array}$ & 44.1 & Alnus nepalensis D.Don & 82.4 & $\begin{array}{l}\text { Crypromeris } \\
\text { japonica D.Don }\end{array}$ & 67.7 \\
\hline $\begin{array}{l}\text { Symplocos } \\
\text { ramosissimaWall. }\end{array}$ & 37.7 & S. ramosissima Wall. & 7.4 & $\begin{array}{l}\text { Pinus roxburghii } \\
\text { Sarg. }\end{array}$ & 18.2 \\
\hline $\begin{array}{l}\text { Rhus wallichii } \\
\text { Hook.f. }\end{array}$ & 3.9 & $\begin{array}{l}\text { Glochidion acuminatum } \\
\text { Müll.Arg. }\end{array}$ & 6.1 & $\begin{array}{l}\text { Pinus wallichiana } \\
\text { A.B.Jacks. }\end{array}$ & 8.4 \\
\hline $\begin{array}{l}\text { Lyonia ovalifolia } \\
\text { (Wall.) Drude }\end{array}$ & 3.4 & $\begin{array}{l}\text { Michelia doltsopa } \\
\text { Buch.-Ham. ex DC. }\end{array}$ & 2.0 & C. hystrix Miq. & 3.2 \\
\hline Total & 89.1 & & 97.9 & & 97.5 \\
\hline
\end{tabular}

OV stems $=$ Proportion of all overstory tree species stems $(\geq 3.2 \mathrm{~cm} \mathrm{dbh})$ encountered

form (i.e., stoloniferous, rhizomatous, or otherwise prostrate). More than twice as many herbaceous graminoid species were encountered per $170 \mathrm{~m}^{2}$ plot in deforested areas than in any other vegetation type $(\mathrm{P}<0.001)$ (Table 1$)$.

Despite the predominance of herbaceous foliage, some woody understory species were encountered regularly, usually together in patches. L. ovalifolia, an overstory tree species, was present as regeneration $(<3.2 \mathrm{~cm} \mathrm{dbh})$ in four of five stands. Associated with patches of woody vegetation were various herbaceous species commonly associated with the forested treatments, including Aconogonum molle, Hypericum choisianum, Impatiens graciliflora, Lepisorus loriformis, Persicaria chinensis, Polypodiodes amoena,
Rubus macilentus, and Rubus rugosus. Deforested areas contained no trees (Table 3). Small woody stems were present in two stands, consisting only of Berberis spp., which are large shrubs, and Symplocos dryophila and Viburnum erubescens, understory trees.

\section{Cardamom plantations}

Cardamom plantations had four distinct layers: (a) overstory trees, (b) understory trees, (c) the A. subulatum subcanopy, and (d) herbaceous groundcover. A. nepalensis was by far the most abundant overstory tree species, accounting for $82.4 \%$ of stems $\geq 3.2 \mathrm{~cm}$ dbh, while G. acuminatum and $S$. ramosissima together contributed an additional $13.5 \%$ (Table 2). The understory

Table 3: Stand structure in four vegetation types in northern Ilam District, Nepal

\begin{tabular}{lllll}
\hline & Primary forest & $\begin{array}{l}\text { Deforested } \\
\text { Areas }\end{array}$ & $\begin{array}{l}\text { Cardamom } \\
\text { plantations }\end{array}$ & $\begin{array}{l}\text { Conifer } \\
\text { plantations }\end{array}$ \\
\hline $\begin{array}{l}\text { Mean dbh of trees } \\
{ }^{1}(\mathrm{~cm})\end{array}$ & $34.3( \pm 19.7)(A)$ & \multicolumn{1}{c}{-} & $20.4( \pm 3.9)(B)$ & $19.5( \pm 2.7)(B)$ \\
& $\begin{array}{l}535.5( \pm 194.9) \\
(B)\end{array}$ & $0.0( \pm 0)(C)$ & $\begin{array}{l}620.5( \pm 227.6) \\
(B)\end{array}$ & $1130.5( \pm 212.3)(A)$ \\
Trees/ha & $709.0( \pm 359.2)$ & $\begin{array}{l}111.1( \pm 272.5) \\
(B)\end{array}$ & $\begin{array}{l}364.9( \pm 304.1) \\
(B)\end{array}$ & $302.5( \pm 197.3)(B)$ \\
$\begin{array}{l}\text { Small woody } \\
\text { stems/ha }{ }^{2}\end{array}$ & $(A)$ & $0.2( \pm 0.5)(C)$ & $22.4( \pm 9.0)(B)$ & $33.9( \pm 10.5)(A, B)$ \\
Basal Area $\left(\mathrm{m}^{2} / \mathrm{ha}\right)$ & $46.0( \pm 29.4)(A)$ & 0 &
\end{tabular}

Standard deviation is given in parentheses. Within a row, $A, B$, and $C$ are significantly different at $\mathrm{P}<0.05$.

${ }^{1}$ Trees are $\geq 10 \mathrm{~cm} \mathrm{dbh}$.

${ }^{2}$ Small woody stems are $\geq 3.2$ and $<10 \mathrm{~cm}$ dbh. 
tree layer contained a large number of species planted to provide fodder for livestock, including L. canum, S. napaulensis, Casearia graveolens, Ficus auriculata, and Ficus neriifolia (Magraw, 2004). Below the understory trees, cardamom formed a tight subcanopy between one and two meters high, averaging more than $70 \%$ canopy closure.

\section{Conifer plantations}

C. japonica occupied the vast majority of the conifer plantation canopy in two stands, and shared the overstory with $P$. wallichiana in a third. In the remaining stand all but one tree were $P$. roxburghii. These three species accounted for almost $95 \%$ of overstory tree species stems, with $C$. hystrix contributing the majority of the remainder (Table 2). Several broad-leafed overstory tree species were present in the conifer understory, including A. alpinum, A. nepalensis, $L$. ovalifolia, and $S$. ramosissima. There were $\sim 31$ woody understory species found in conifer plantations (Magraw, 2004).

\section{Comparisons among vegetation types}

Species richness in primary forests and conifer plantations was almost $50 \%$ greater than that in deforested areas and cardamom plantations in $170 \mathrm{~m}^{2}$ plots ( $\left.\mathrm{P} \leq 0.001\right)$ (Fig. 3). In $1 \mathrm{~m}^{2}$ quadrats, however, the only vegetation type found to be significantly distinct $(\mathrm{P} \leq 0.001)$ was cardamom, which contained $40-46 \%$ fewer species than the other vegetation types (Fig.3). Cover of vegetation $<1 \mathrm{~m}$ above the forest floor was greater in primary forests and deforested areas than in conifer and cardamom plantations $(\mathrm{P}<0.05)$ (Table 1$)$.

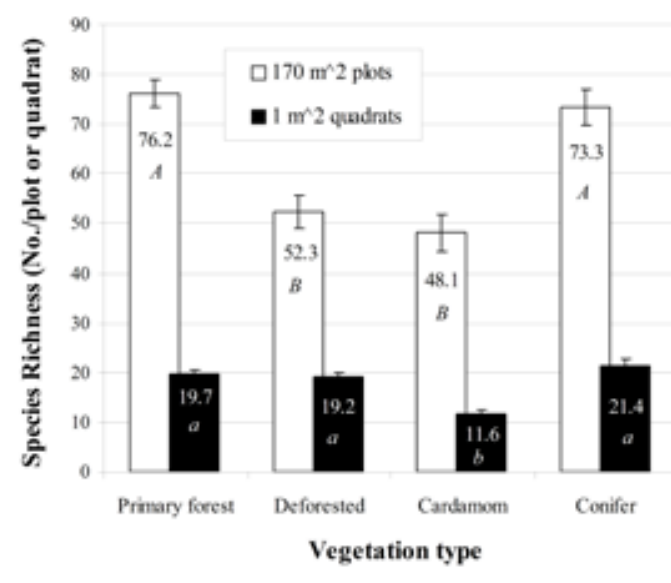

Fig. 3: Mean species richness $( \pm$ S.E. $)$ in 170 $\mathrm{m}^{2}$ plots and $1 \mathrm{~m}^{2}$ quadrats in four vegetation types in northern Ilam District, Nepal. A and B are significantly different at $P \leq 0.001$. $a$ and $b$ are significantly different at $\mathbf{P} \leq \mathbf{0 . 0 0 1}$
Conifer plantations had the highest ShannonWiener index values and cardamom plantations had the lowest $(\mathrm{P}<0.01)$ with primary forests and deforested areas exhibiting intermediate, but statistically indistinguishable, diversity (Table 1). Conifer plantations had a higher species overlap with all other vegetation types than any of the remaining vegetation types had with one another (Table 4). The lowest overlap (0.30) was between primary forests and deforested areas. Primary forests had the highest proportion of unique species $(30 \%)$ and conifer plantations had the lowest (16\%) (Table 1$)$.

Table 4: Jaccard's Coefficients of overlap, calculated from species encountered in $170 \mathrm{~m}^{2}$ plots, among four vegetation types in northern Ilam District, Nepal

\begin{tabular}{lccc}
\hline & $\begin{array}{c}\text { Defor- } \\
\text { ested }\end{array}$ & $\begin{array}{c}\text { Carda- } \\
\text { mom }\end{array}$ & $\begin{array}{c}\text { Coni- } \\
\text { fer }\end{array}$ \\
\hline Primary forest & 0.30 & 0.38 & 0.47 \\
Deforested & 1.00 & 0.34 & 0.43 \\
Cardamom & -- & 1.00 & 0.44 \\
Conifer & -- & -- & 1.00 \\
\hline
\end{tabular}

The density and size distribution of woody stems varied widely between vegetation types. Primary forests had greater variability in dbh and greater basal area than conifer and cardamom plantations (Table 3). There were fewer trees/ha in primary forests, but the density of small woody stems was roughly twice that of the plantations, and the largest trees in primary forests had approximately three times greater dbh than those in cardamom and conifer plantations. Regarding canopy composition, there were nine species with stems larger than $20 \mathrm{~cm}$ dbh in primary forests, and four species each in conifer and cardamom plantations (three of the four were planted in both plantation types).

\section{Discussion}

There were substantial differences in plant community composition among vegetation types, likely resulting from differences in the degree of management and disturbance as well as from patterns in the distribution of vegetation types on the landscape. The results support our predictions that primary forests and conifer plantations have greater plant species richness and diversity than deforested areas and cardamom plantations. The expectation that conifer plantations would be less diverse and species-rich than primary forests was 
supported by some measures and not by others. Lower replication in primary forests and conifer plantations is likely to result in underestimation of species richness and diversity, particularly among locally rare species, relative to cardamom plantations and deforested areas. Some taxonomic groups, such as Orchidaceae and Araceae, were not well sampled in this study because many species were not present above ground during the two months of data collection. Epiphytic species were likely undercounted because they were difficult to detect and identify in the canopy. Other taxa were undercounted because, although recorded, they were not positively identified.

\section{Aspect and elevation}

In Eastern Nepal, north- and west-facing slopes contain distinct, and typically more diverse, plant communities than south- and east-facing slopes (Stainton, 1972). The elevation range of the stands sampled, 1,950 to $2,550 \mathrm{~m}$, corresponds closely with the limits of the Lower Temperate Zone (TISC/NARMSAP, 2002). Nevertheless, canopy composition in primary forests showed differences along this elevation gradient among the stands sampled. Thus, aspect and elevation likely contributed to the observed differences in plant communities. These confounding environmental factors limit the extent to which differences in plant community composition observed in this study can be correlated with vegetation type. They also suggest avenues for further study to understand the effects of human activities on the distribution of natural communities across the landscape.

\section{Primary forests}

In Eastern Nepal's Lower Temperate Zone, and throughout the Middle Hills, primary forests have been increasingly restricted to higher elevations as the natural forests below $2,500 \mathrm{~m}$ have diminished. Grazing, fodder cutting, or fuel-wood removal had visibly affected all primary forest plots sampled, and timber felling was evident in several. Among overstory species, L. pachyphylla persisted only as regeneration and Q. lamellosa was found only in the canopy. Michelia doltsopa, a popular and lucrative timber species, had been recorded in the Lower Temperate Zone in the past (Stainton, 1972; TISC/NARMSAP, 2002), but was entirely absent from primary forest plots.

Relatively infrequent utilization by humans and the sheltered, mesic microclimate on north-facing slopes are likely responsible for the complex and diverse plant communities in primary forests.
Some characteristics of primary forests that illustrate this complexity are high understory and canopy species richness, high variability in size of woody stems, and abundance of unique species and specialized-niche functional groups. Conditions in conifer and cardamom plantations are less favorable for these functional groups as dead trees and climbing plants are removed, and cardamom plantations are logged periodically (the conifer plantations were not sufficiently mature for logging).

Comparatively low species overlap among primary forests, deforested areas, and cardamom plantations likely results in large part from modification of forest structure and composition by humans in the latter two vegetation types. Comparatively high species overlap between primary forests and conifer plantations can be explained in part by their shared characteristics: a lack of ongoing intensive management (as compared to cardamom plantations), similarity in structure (as compared to deforested areas), and their position on the landscape (predominantly on north- and west-facing slopes).

\section{Deforested areas}

Without an overstory, there are opportunities in deforested areas for species unable to tolerate shade. Deforested areas contained $\sim 47$ species not found in any other vegetation type, many of which were herbaceous graminoids and plants with a spreading growth form. Woody vegetation in deforested stands was minimized by removal of fuel-wood and regular grazing. However, some woody species that were fast-growing or exhibited anti-herbivory adaptations (e.g., the spines of Berberis spp., thorns of Rubus ellipticus, and poisonous foliage of $L$. ovalifolia) were encountered regularly. These species persisted as islands of woody vegetation and appeared to provide refuge for plant species intolerant of exposure and herbivory. Such islands might serve as important sources of diversity should forests become reestablished.

Previous research has found that the greatest causal factors for deforestation in this region are conversion to agriculture, livestock grazing, and removal of timber and fuel-wood (Mahat et al., 1987; Blaikie, 1988; Chaudhary, 2000). None of the deforested sites were under cultivation at the time of sampling, though it is likely that some had been previously cultivated. All sites were grazed, and many containing woody vegetation were being 
utilized as a source for fuel-wood. In contrast with deforested areas, both primary forests and cardamom plantations are well established with a damp, well-shaded understory. Thus, the low species overlap between deforested areas and these vegetation types is to be expected. The conifer stands had been planted on deforested land 10-30 years previously, a possible explanation for the comparatively high species overlap between these two vegetation types.

\section{Cardamom plantations}

Intensive management appears to be the greatest factor affecting species richness and diversity in cardamom plantations. Woody vegetation is controlled by farmers who prefer species that fix nitrogen and produce high quality timber and fodder. Cardamom occupies a substantial proportion of the ground-surface and forms a second canopy between one and two meters above ground. The groundcover is thinned several times yearly to reduce interspecific competition and physical interference with cardamom flowers and fruit.

Sharma et al. (1998b) have described cardamom plantations as a successful combination of income generation and biodiversity conservation. This is reasonable when considering alternatives such as terraced cultivation and monoculture plantations. But, of the vegetation types we examined, cardamom plantations are among the least diverse and species rich, and so are not a viable conservation alternative to primary forests.

\section{Conifer plantations}

Conifer forests do not undergo intensive manipulation of the understory, as in cardamom plantations, or frequent, unregulated resource extraction, as in deforested areas. This, in combination with difference in aspect and elevation, may account for the significantly greater species richness in conifer plantations as compared to deforested areas and cardamom plantations.

The expectation that conifer plantations would exhibit lower species richness and diversity than primary forests was not met. This prediction was based on the assumptions that (a) overstory and understory tree species richness in conifer plantations would be lower than that in primary forests, and (b) conifer leaf litterfall would alter the soil chemistry, inhibiting growth of understory plants (Samra and Raizada, 2002). The reduction in diversity of conifer plantations previously documented by Sitaula (2000) and others may not have occurred here because the plantations were found predominantly on north-facing slopes and were only $10-30$ years old.

Conifer plantations are established upon deforested lands, so as they mature they transition from a community dominated by species tolerant to exposure and grazing to one with an understory more typical of forests. As their high overlap with other vegetation types suggests, the conifer plantation understory contains a combination of species typical of other management types. The presence of many overstory and understory tree species in the conifer understory suggests the possibility of a mixed forest in the future. However, this is unlikely in these plantations due to the high density of even-aged conifers, occasional removal of undesirable species and undergrowth by Community Forest Users Groups, and alteration of soil chemistry by conifer leaf litter.

Several aspects of the undergrowth in conifer plantations differ remarkably from primary forests. Even though species diversity and overall species richness were not significantly different, mean vegetation cover and richness of epiphytic and climbing species were lower in conifer plantations than in primary forests. Moreover, the proportion of unique species in conifer plantations was the lowest of any vegetation type, whereas primary forests had the highest proportion of unique species. So, even though species richness and diversity in conifer plantations were comparable to that in primary forests, the species that occurred in conifer plantations were more likely to be found in other vegetation types as well.

This study combined plantations consisting of two Pinus species and C. japonica into one vegetation type. Differences in the density of the canopy and leaf litter between C.japonica and the Pinus species will likely result in distinct plant communities under a mature canopy.

\section{Conclusion}

Our findings suggest that plant communities in eastern Nepal's Lower Temperate Zone are strongly influenced by the type and degree of management and by their location on the landscape. Consequently, although estimates of total forest cover are useful in assessing the overall condition of the landscape and the resources available to rural communities, they should not be considered a gauge of the continued presence 
of species-rich plant communities approximating those in primary forests.

No single vegetation type contained more than $60 \%$ of the species encountered in this study. The most species-rich landscape, therefore, most likely consists of a patchwork of vegetation and land-use types. There are currently few direct incentives for rural Nepalese to maintain natural vegetation types as part of the landscape mosaic. Instead, as population has increased, primary forests near human settlements have diminished, being replaced by land-use types that serve the local people's needs.

Future research should consider the likelihood of natural forest regeneration from deforested areas, loss of habitat on south- and east-facing hillsides, and viability of forest plant communities in an increasingly patchy landscape.

\section{Acknowledgements}

We are grateful to Dinesh Karki for his support, technical and otherwise, and to Netra Burja Thapa and the family of Dan Bahadur Rai in northern Ilam. We would like to express our sincere thanks to a number of the employees of Department of Plant Resources of Nepal and to various faculty members at Colorado State University. We are thankful to the Peace Corps Masters/Internationalist Program, Peace Corps/ Nepal, Nepal's Ministry of Forests and Soil Conservation, and Colorado State University's Graduate Degree Program in Ecology for their generous support to carry out this study.

\section{References}

Acharya, B. 1999. Forest Biodiversity Assessment: A Spatial Analysis of Tree Species Diversity in Nepal. International Institute for Aerospace Survey and Earth Sciences, Enschede, The Netherlands.

Acharya, K.P. 2006. Linking trees on farms with biodiversity conservation in subsistence farming systems in Nepal. Biodiversity and Conservation 15: 631-646.

Blaikie, P. 1988. The explanation of land degradation. InDeforestation: Socialdynamics in watershes and mountain ecosystems (eds.) Ives, J., Pitt, D.C. Routledge, London, U.K, $132-158$.

Branney, P. and Dev, O.P. 1994. Biodiversity Implications of Community Management of Forests in Nepal. Nepal-UK Community
Forestry Project Report 12/NUKCFP/04, Kathmandu, Nepal.

Branney, P. and Yadav, K.P. 1998. Changes in Community Forest Condition and Management 1994-1998: Analysis of Information from the Forest Resource Assessment Study and Socio-Economic Study in the Koshi Hills. Project Report G/ NUKCFP/32, Nepal-UK Community Forestry Project and HMG, Kathmandu, Nepal.

Brown, S. and Shrestha, B. 2000. Market-driven land use dynamics in the Middle Mountains of Nepal. Journal of Environmental Management 59: 217-225.

Chaudhary, R.P. 2000. Forest conservation and environmental management in Nepal: A review. Biodiversity and Conservation 9: 1235-1260.

DPR. 2002. Pteridophytes of Nepal. Department of Plant Resources, Ministry of Forests and Soil Conservation, Kathmandu, Nepal.

DPR. 2001. Flowering Plants of Nepal (phanerogams). Department of Plant Resources, Ministry of Forests and Soil Conservation, Kathmandu, Nepal.

Gautam, A.P., Webb, E.L., Shivakoti, G.P. and Zoebisch, M.A. 2003. Land use dynamics and landscape change pattern in a mountain watershed in Nepal. Agriculture, Ecosystems and Environment 99: 83-96.

Gilmour, D.A. 1995. Rearranging trees in the landscape in the Middle Hills of Nepal. In Farms, trees and farmers; responses to agricultural intensification (eds) Arnold, J.E.M. and Dewees, P.A. Earthscan Publications Ltd., London, UK, 21-42.

Gurevitch, J., Scheiner, S.M. and Fox, G.A. 2002. The Ecology of Plants. Sinauer Associates, Inc., Sunderland, Massachusetts, USA.

HMGN/MFSC. 2000. Revised Forestry Sector Policy 2000. His Majesty's Government, Nepal/Ministry of Forests and Soil Conservation, Kathmandu, Nepal.

Hara, H. 1966. The Flora of Eastern Himalaya. University of Tokyo Press, Tokyo, Japan.

Ibscher, A. 1999. Biodiversity in Community Forests. Assessment in Different Forest Types in the Middle Hills of Nepal, Based on the Experiences Observed in three FUG's in Dolakha and Ramechap Districts. Swiss Agency for Development and Cooperation, Kathmandu, Nepal. 
Jaccard, P. 1901. Distribution de la flore alpine dans le Bassin des Dranes et dans quelques régions voisines. Bulletin de la Société vaudoise des sciences naturelles 37: 241-272.

Jackson, W.J., Tamrakar, R.M., Hunt, S. and Shepherd, R. 1998. Land-use changes in two Middle Hills Districts of Nepal. Mountain Research and Development 18: 193-212.

Magraw, K.N.L. 2004. Beyond Forest Cover: An Analysis of Plant Communities in the Fragmented Rural Landscape of Northern Ilam District, Nepal. M.Sc. Thesis, Graduate Degree Program in Ecology, Colorado State University, Fort Collins, Colorado, USA.

Mahat, T.B.S., Griffin, D.M. and Sheperd, K.R. 1987. Human impact on some forests of the Middle Hills of Nepal. Part 3. Forests in the subsistence economy of Sindhu Palchok and Kabhre Palanchok. Mountain Research and Development 7: 111-134.

Metz, J.J. 1991. A reassessment of the causes and severity of Nepal's environmental crisis. World Development 19: 805-820.

Mikkola, K. 2002. Community Forestry's Impact on Biodiversity Conservation in Nepal. M.Sc. Dissertation, University of London, Imperial College at Wye, London, UK.

Namsaling Community Development Centre. 2002. Periodic Sustainable Development Plan for Pashupatinagar VDC, Ilam, Nepal. Unpublished Draft Report.

Paudel, G.S. and Thapa, G.B. 2001. Changing farmers' land management practices in the hills of Nepal. Environmental Management 28: 789-803.

Rai, L.R. 1999. Flora of Maipokhari and Adjoining Areas, Ilam District (East Nepal). M.Sc. Thesis, Central Department of Botany, Tribhuvan University, Kiritipur, Nepal.

Samra, J.S. and Raizada, A. 2002. Litter production and nutrient dynamics in tropical forest plantations of India. In Management of tropical plantation-forests and their soil litter system. Litter biota and soil-nutrient dynamics (ed) Reddy, M.V. Science Publishers, Inc., Enfield, New Hampshire, USA, 41-72.

Schreier, H., Brown, S., Schmidt, M., Shah, P., Shrestha, B., Nakarmi, G., Subba, K. and Wymann, S. 1994. Gaining forests but losing ground: A GIS evaluation in a Himalayan watershed. Environmental Management 18: $139-150$.
Sharma, E., Sharma, R. and Pradhan, M. 1998a. Ecology of HimalayanAlder(Alnusnepalensis D. Don). PINSA 64B: 59-78.

Sharma, R., Singh, K.K. and Sharma, E. 1998b. Large Cardamom farming: An appropriate livelihood option for the mountain people. In Research for mountain development. G.B. Pant Institute of Himalayan Environment and Development, Nainital, India.

Shrestha, B. 1998. Involving local communities in conservation: the case of Nepal. In Communities and conservation. Natural resource management in south and central Asia (eds) Kothari, A., Pathak, N., Aruradha, R.V. and Taneja, B. Sage Publications, New Delhi, India, 130-147.

Sitaula, M.K. 2000. Biodiversity Management in the Mid Hills; a Case Study of Different Forest User Groups of Dolakha and Ramechap Districts. Ph.D. Dissertation, Central Department of Sociology/Anthropology, Tribhuvan University, Kathmandu, Nepal.

Stainton, J.D.A. 1972. Forests of Nepal. The Camelot Press, London, UK.

TISC/NARMSAP. 2002. Forest and Vegetation Types of Nepal. Tree Improvement and Silviculture Component, Natural Resources Management Sector Assistance Programme, Kathmandu, Nepal.

UNDP. 1998. Ecoregional Co-operation for Biodiversity Conservation in the Himalaya. Report of the International Meeting on Himalaya Ecoregional Co-operation, Kathmandu, Nepal. February 16-18, 1998. United Nations Development Programme, New York, USA.

USDA Forest Service. 2005. Phase 3 Field Guide - Vegetation Diversity and Structure. Forest Inventory and Analysis National Program. U.S. Department of Agriculture. URL: http:// fia.fs.fed.us/library/field-guides-methodsproc/docs/2006/p3_3-0_sec13_10_2005.pdf (Accessed on 3-21-2012).

Wilkinson, L. 2000. SYSTAT. Version 10. SYSTAT Software, Inc., Point Richmond, California, USA. 